\title{
THE RELATIONSHIP OF LEARNING MOTIVATION, DISCIPLINE OF STUDENTS AND RESPONSIBILITIES OF LEARNING STUDENTS ON THE LEARNING RESULTS OF MATHEMATICS STUDENTS OF SMA NEGERI 1 PLERET
}

\author{
Retno Nurhayatia, Abdul Taram. ${ }^{\text {b }}$ \\ Program Studi Pendidikan Matematika Universitas Ahmad Dahlan \\ Jalan Ring Road Selatan, Tamanan, Banguntapan, Bantul Yogyakarta \\ aretnonurhayati47@gmail.com, ${ }^{b}$ taromahmad@yahoo.com
}

\begin{abstract}
Low student learning outcomes are influenced by many factors. Learning motivation, student discipline and student learning responsibilities are several factors related to learning outcomes. This study aims to determine whether or not there is a positive and significant relationship between learning motivation, student discipline and student learning responsibilities with mathematics learning outcomes of XI IPS students in the even semester of SMA Negeri 1 Pleret Bantul Regency 2015/2016 Academic Year. The population of this study were all students of class XI IPS even semester of SMA Negeri 1 Pleret Bantul Regency in the 2015/2016 Academic Year consisting of 3 classes with a total of 72 students. Samples were taken by random sampling technique and obtained class XI IPS 2 as a sample class. Data collection techniques were carried out using the test and questionnaire method. The test method was used to collect data on student learning outcomes, while the questionnaire method was used to collect learning motivation, student discipline, and responsibility data, answer learning. The instrument test uses a validity test, a different power test, and a reliability test. Analysis prerequisite test is a normality test, independent test, linearity test. Data analysis for hypothesis testing uses correlation analysis and linear regression analysis. The results showed that there was a positive and significant relationship between learning motivation, student discipline and learning responsibilities with learning outcomes $F_{\text {count }}=3,3725$ dan $F_{\text {table }}=3,16$ so obtained $F_{\text {count }} \geq F_{\text {table }}$. The multiple correlation coefficient (R) of 0.5998 with the regression equation $\hat{Y}=-73,3307+0,3358 X_{1}+0,4425 X_{2}+$ $0,5854 X_{3}$ the relative contribution of $\mathrm{X}_{1}=32.984 \%, \mathrm{X}_{2}=35.149 \%, \mathrm{X} 3=31.867 \%$ with a double determination coefficient $\left(\mathrm{R}^{2}\right) 0.3598$ and effective contribution $\mathrm{X}_{1}=11.868 \%,=12.664 \%, \mathrm{X}_{3}=$ $11.467 \%$.
\end{abstract}

Keywords: Learning Motivation, Student Discipline, Learning Responsibility, Learning Outcomes of Mathematics

\section{INTRODUCTION}

Education is one of the most important things for the progress of a nation. We need to know that education will succeed to the maximum if every element of education from the bottom up can be oriented towards national education goals. As for the objectives of national education according to Law No. 20 of 2003 Chapter II article 3 which reads: National Education functions to develop ability and shape the character and civilization of a dignified nation in the context of educating the nation's life. aims to develop the potential of students to become human beings who believe and devote to God Almighty, noble, healthy, knowledgeable, capable, creative, independent, and become citizens.

Mathematics is one of the subjects taught starting from Elementary Schools, Middle Schools, High Schools / Vocational Schools, and Universities. Mathematics is a basic and compulsory subject. Mathematics learning is given to students to equip students with the ability to think logically, critically, creatively, analysis, and the ability to cooperate. There are several factors that affect learning, especially learning mathematics. Learning is influenced by several factors, namely internal factors are factors that originate from within humans, including physical and psychological factors. While external factors come from outside the individual. The results of learning mathematics at SMA Negeri 1 Pleret Bantul Regency are very low. This is because, by many factors including student motivation to learn mathematics is still lacking, students have a low level of discipline, student learning responsibilities are still low. According to Sardiman (2012: 102), Learning motivation is the overall driving force of the self 
within students that gives rise to, guarantees continuity and provides direction for learning activities, so it is expected that the goals can be achieved. Therefore students must have an increased learning motivation so that the learning outcomes achieved will also be good.

Internal factors that are thought to influence further are discipline. According to Rasdiyanah, Andi in Amri, Sofan (2013: 168) discipline is compliance to respect and implement a system that requires people to submit to decisions, orders or regulations. According to Diar, Rudyanto (2010: 22), Discipline of time can include: being on time in learning, not going out or skipping classes, completing assignments in accordance with the specified time. While work discipline or perversion include: obedient and not against the rules, not lazy to learn, not asking others to work for him, do not like to lie, and pleasant behavior. In addition, learning responsibilities are thought to influence learning outcomes. As revealed according to Bahri in Sartono (2002) responsibility is an obligation of a person to carry out what has been required to him or that has been promised to him or that he agreed. A simple definition of learning responsibility can be formulated, namely that responsibility can be described as a person's attitude and behavior to carry out the rights and obligations as individuals that should be done for oneself, other people and God Almighty, in other words, a person must bear all actions he did.

The problem in this research is: 1) Is there a positive and significant relationship between learning motivation and Mathematics Learning Outcomes of XI IPS Class Students Even Semester SMA Negeri 1 Pleret Bantul Regency Academic Year 2015/2016? 2) Is there a positive and significant relationship between student discipline with Student Mathematics Learning Outcomes class XI IPS Even Semester of SMA N 1 Pleret Bantul Regency 2015/2016 Academic Year?, 3) Is there a positive and significant relationship between student learning responsibilities with Mathematics Learning Outcomes Class XI IPS even semester of SMA Negeri 1 Pleret Bantul Regency in 2015 Academic Year / 2016?, 4) Is there a positive and significant relationship between learning motivation and student discipline with Mathematics Learning Outcomes of XI IPS Class Students Even Semester of SMA Negeri 1 Pleret Bantul Regency Academic Year 2015/2016?, 5) Is there a positive and significant relationship between learning motivation and student learning responsibilities with Mathematics Learning Outcomes Grade XI IPS Even Semester SMA Negeri 1 Pleret Bantul Regency 2015/2016 Academic Year?, 6) Is there a positive and significant relationship between student discipline and student learning responsibilities with mathematics learning outcomes of students of class XI IPS in SMA Negeri 1 Pleret 2015/2016 academic year?, 7) Is there a positive relationship and significant between learning motivation, student discipline and student learning responsibility with Mathematics Learning Outcomes XI IPS Class students Even Semester of SMA Negeri 1 Pleret Bantul Regency Academic Year 2015/2016?

The purpose of this study is 1) Knowing whether or not there is a positive and significant relationship between learning motivation and Mathematics Learning Outcomes of XI IPS Grade Students of Even Semester at SMA Negeri 1 Pleret Bantul Regency, Academic Year 2015/2016. 2) Knowing whether or not there is a positive and significant relationship between student discipline and Mathematics Learning Outcomes of XI IPS Class Students Even Semester of SMA Negeri 1 Pleret Bantul Regency Academic Year 2015/2016. 3) Knowing whether or not there is a positive and significant relationship between students' learning responsibilities and Mathematics Learning Outcomes of XI IPS Class Students Even Semester of SMA Negeri 1 Pleret Bantul Regency Academic Year 2015/2016. 4) Knowing whether or not there is a positive and significant relationship between learning motivation and student discipline with Mathematics Learning Outcomes Grade XI IPS students Even Semester of SMA Negeri 1 Pleret Bantul Regency Academic Year 2015 / 2016.5) Knowing whether or not there is a positive and significant relationship between learning motivation and student learning responsibilities with Mathematics Learning Outcomes Grade XI IPS students in the Even Semester of SMA Negeri 1 Pleret Bantul Regency Academic Year 2015/2016. 6) Knowing whether or not there is a positive and significant relationship between student discipline and student learning responsibilities with Mathematics Learning Outcomes of XI IPS Class Students Even Semester of SMA Negeri 1 Pleret Bantul Regency 2015/2016 Academic Year. 7) Knowing whether or not there is a positive and 
significant relationship between learning motivation, student discipline and student learning responsibilities with Mathematics Learning Outcomes XI IPS Class Students Even Semester of SMA Negeri 1 Pleret Bantul Regency 2015/2016 Academic Year.

\section{METHODS}

This research is classified as quantitative by taking place at SMA Negeri 1 Pleret in the even semester of the academic year 2015/2016. The population in this study were all students of class XI IPS in the even semester of SMA Negeri 1 Pleret consisting of 3 classes namely Xi IPS 1, XI IPS 2, XI IPS 3 totaling 72 students. As a sample class, students took class XI IPS 2 as many as 22 students using random sampling techniques. In this study, the data collection method used was the questionnaire and test method. The questionnaire method was to obtain data on learning motivation, student discipline and learning responsibility while the test method was to obtain student learning outcomes data.

The test used is the analysis prerequisite test with the Chi-squared formula normality test, the linearity test of the F-test formula and the Chi-squared formula independence test. Research hypothesis testing uses a simple correlation test, multiple regression analysis test and multiple linear regression test with three independent variables. Research hypothesis testing using a simple correlation test is performed to determine whether there is a positive and significant relationship between 1) learning motivation with student mathematics learning outcomes, 2) student discipline with student mathematics learning outcomes and 3) learning responsibilities with student mathematics learning outcomes. Furthermore, the research hypothesis test uses a multiple regression analysis tests conducted to determine whether there is a positive and significant relationship between 1) student motivation and discipline with student mathematics learning outcomes, 2) learning motivation and learning responsibility with student mathematics learning outcomes, 3 ) discipline and learning responsibilities with student mathematics learning outcomes. Whereas the multiple linear regression test with three independent variables was conducted to find out whether or not there was a positive and significant relationship between learning motivation, discipline and the learning environment with student mathematics learning outcomes.

\section{RESULTS AND DISCUSSION}

\section{Test Prerequisite Regression Analysis}

The summary of the results of the initial ability normality test can be seen in Table 1 .

Table 1. Summary of Normality Test Results

\begin{tabular}{|l|c|c|c|}
\hline Variable & $x_{\text {count }}^{2}$ & $x_{\text {table }}^{2}$ & $\mathrm{dk}$ \\
\hline $\begin{array}{l}\text { Learning motivation } \\
\left(\mathrm{X}_{1}\right)\end{array}$ & 0,2517 & 3,81 & 1 \\
\hline Discipline $\left(\mathrm{X}_{2}\right)$ & 1,9925 & 5,991 & 2 \\
\hline $\begin{array}{l}\text { Learning } \\
\text { Responsibility }\left(\mathrm{X}_{3}\right)\end{array}$ & 2,3924 & 5,991 & 2 \\
\hline $\begin{array}{l}\text { Mathematics learning } \\
\text { outcomes (Y) }\end{array}$ & 0,7547 & 5,991 & 2 \\
\hline
\end{tabular}

Seen $x_{\text {count }}^{2} \leq x_{\text {table }}^{2}$, this means that from the normality test at a significant level of $5 \%$ that the distribution of data obtained on each variable is normally distributed. The summary of linearity test results can be seen in Table 2 .

Table 2. Summary of Linearity Test Results

\begin{tabular}{|l|c|c|}
\hline Variable & $F_{\text {count }}$ & $F_{\text {table }}$ \\
\hline $\mathrm{X}_{1}$ to $\mathrm{Y}$ & 0,9123 & 2,9 \\
\hline $\mathrm{X}_{2}$ to $\mathrm{Y}$ & 0,3607 & 2,8 \\
\hline $\mathrm{X}_{3}$ to $\mathrm{Y}$ & 0,3736 & 2,85 \\
\hline
\end{tabular}


From the linearity test at a significant level of 5\% and the degrees of freedom $\mathrm{v}_{1}$ the numerator k-2 and $\mathrm{v}_{2}$ denominator are seen $F_{\text {count }} \leq F_{\text {table }(1-\alpha)(k-2, N-k)}$, this means that there is a linear relationship between the independent variable $(\mathrm{X})$ and the dependent variable $(\mathrm{Y})$.

The summary of independent test results can be seen in Table 3 .

Table 3. Summary of Independence Test Results

\begin{tabular}{|l|c|c|l|}
\hline Variable & $x_{\text {count }}^{2}$ & $x_{\text {table }}^{2}$ & $\mathrm{df}$ \\
\hline $\mathrm{X}_{1}$ and $\mathrm{X}_{2}$ & 21,282 & 26,296 & 16 \\
\hline $\mathrm{X}_{1}$ and $\mathrm{X}_{3}$ & 14,850 & 26,296 & 16 \\
\hline $\mathrm{X}_{2}$ and $\mathrm{X}_{3}$ & 23,797 & 26,296 & 16 \\
\hline
\end{tabular}

From the independent test at a significant level of 5\% and the degree of freedom (df) $=(\mathrm{k}-$ 1) (b-1) seen $x_{\text {count }}^{2} \leq x_{\text {table }}^{2}$, this means that the distribution of data obtained on each variable is independent.

\section{Hypothesis Testing}

In the first hypothesis test, a simple correlation coefficient $r$ of 0.5569 was obtained at a significant level of 5\%. In order to get the determinant coefficient $\mathrm{r} 2$ of 0.3101 which can be explained that $31.01 \%$ learning outcomes are influenced by learning motivation while the rest is influenced by other factors. There are variations in learning outcomes in mathematics $(\mathrm{Y})$ which are explained by learning motivation $\left(\mathrm{X}_{1}\right)$ through linear lines $\hat{\mathrm{Y}}=-23,04202+0,87771 \mathrm{X}_{1}$. The first hypothesis test result is that there is a positive and significant relationship between learning motivation and mathematics learning outcomes. In other words, the higher the child's learning motivation, the better the child's learning outcomes.

In the second hypothesis test, a correlation coefficient (r) of 0.54328 was obtained at a significant level of 5\%. So the determinant coefficient $\left(\mathrm{r}^{2}\right)$ of 0.2952 can be obtained which can explain $29.52 \%$ of learning outcomes influenced by discipline while the rest is influenced by other factors. There are variations in mathematics learning outcomes $(\mathrm{Y})$ explained by discipline $\left(\mathrm{X}_{2}\right)$ through linear lines $\hat{Y}=-41,84569+1,03263 \mathrm{X}_{2}$. The second hypothesis test result is that there is a positive and significant relationship between student discipline and mathematics learning outcomes. In other words, the higher the student's discipline, the higher the learning outcomes.

In the third hypothesis test, the correlation coefficient (r) obtained is 0.44603. So it is obtained $\left(\mathrm{r}^{2}\right)$ of 0.1989 which can explain $19.89 \%$ of learning outcomes influenced by learning responsibilities while the rest is influenced by other factors. There are variations in mathematics learning outcomes $(\mathrm{Y})$ explained by learning responsibilities $\left(\mathrm{X}_{3}\right)$ through linear lines $\hat{\mathrm{Y}}=$ $38,45734+1,01563 \mathrm{X}_{3}$. The third hypothesis test result is that there is a positive and significant relationship between learning responsibilities with mathematics learning outcomes. In other words, the better the responsibility of learning, the mathematical learning outcomes will also be good.

From the multiple correlation analysis, the fourth hypothesis test obtained the value of the multiple correlation coefficient (r) of 0.62273 . In this study also obtained a coefficient of determination $\left(\mathrm{r}^{2}\right)$ of 0.3877 meaning $38.77 \%$ of learning outcomes are influenced by learning motivation and discipline while the rest is influenced by other factors. There are variations in mathematics learning outcomes $(\mathrm{Y})$ which can be explained by learning motivation $\left(\mathrm{X}_{1}\right)$ and discipline $\left(\mathrm{X}_{2}\right)$ through linear lines $\hat{Y}=-58.80406+0.57974 \mathrm{X}_{1}+0.63987 \mathrm{X}_{2}$. As for the relative contribution of $X_{1}$ by $52.84 \%$ and $X_{2}$ by $47.16 \%$ and the effective contribution of $X_{1}$ by $20.49 \%$ and $\mathrm{X}_{2}$ by $18.28 \%$. The fourth hypothesis test results are there is a positive and significant relationship between learning motivation and discipline with the results of learning mathematics. In other words, the higher the motivation of students to learn mathematics, the children's learning outcomes will also be better. Likewise with discipline, the higher the discipline of children, the better the learning outcomes.

From the multiple correlation analysis the fifth hypothesis test obtained by the multiple correlation coefficient values of 0.6137 . In this study also obtained a coefficient of determination of 0.3767 meaning $37.67 \%$ of learning outcomes are influenced by learning motivation and 
learning responsibility while the rest is influenced by other factors. There are variations in mathematics learning outcomes that can be explained by learning motivation and learning responsibilities through linear lines $\hat{Y}=-70.2827+0.7154 \mathrm{X}_{1}+0.6231 \mathrm{X}_{3}$. As for the relative contribution of $67.12 \%$ and $32.87 \%$ and the effective contribution of $25.28 \%$ and $12.83 \%$. The fifth hypothesis test result is a positive and significant relationship between learning motivation and learning responsibility with results learning mathematics. In other words, the higher the child's motivation to learn mathematics, the better the child's learning outcomes. Likewise with learning responsibilities, the better the learning responsibilities of children, the better the learning outcomes.

From the double correlation analysis the sixth hypothesis test obtained by the value of the multiple correlation coefficient of 0.5520 . In this study also obtained a coefficient of determination of 0.3047 meaning $30.47 \%$ of learning outcomes are influenced by discipline and learning responsibility while the rest is influenced by other factors. There are variations in mathematics learning outcomes that can be explained by discipline and learning responsibilities through linear lines $\hat{\mathrm{Y}}=-54.6289+0.8546 \mathrm{X}_{2}+0.30882 \mathrm{X}_{3}$. As for the relative contribution of $80.15 \%$ and $19.84 \%$ and the effective contribution of $24.42 \%$ and $6.049 \%$. The sixth hypothesis test result is a positive and significant relationship between discipline and responsibility for learning with learning outcomes in mathematics. In other words, the higher the level of discipline students have, the better the learning outcomes, apart from that students who have supportive learning responsibilities, the better the learning outcomes.

From the double correlation analysis, the seventh hypothesis test obtained the value of the multiple correlation coefficient of 0.5998 . This study also obtained a coefficient of determination of 0.3598 meaning $35.98 \%$ is influenced by learning motivation, discipline and learning responsibility while the rest by other factors. Variations in mathematics learning outcomes can be explained by learning motivation, discipline, and learning responsibilities through linear lines $\hat{Y}=$ $73.3307+0.3358 \mathrm{X}_{1}+0.4425 \mathrm{X}_{2}+0.5854 \mathrm{X}_{3}$. As for the relative contribution of $32.98 \%$, amounting to $35.14 \%$ and amounting to $31.86 \%$ and an effective contribution of $11.86 \%$, amounting to $12.64 \%$ and amounting to $11.46 \%$. The seventh hypothesis test results are there is a relationship positive and significant between learning motivation, discipline and learning responsibility with mathematics learning outcomes. In other words, the better the motivation to learn, the better the learning outcomes will be. Likewise with discipline, the higher the discipline of children, the higher the learning outcomes. In addition, the responsibility of learning also influences learning outcomes, because the better and support the learning responsibilities, the higher the learning outcomes.

\section{CONCLUSION}

1. There is a positive and significant relationship between learning motivation and mathematics learning outcomes of students of class XI IPS in the even semester of SMA Negeri 1 Pleret in the 2015/2016 Academic Year. The simple correlation coefficient (r) between learning interest and mathematics learning outcomes is 0.5569 . And the simple regression equation $\mathrm{Y}$ for $\mathrm{X}_{1}$ is $\mathrm{Y}^{\wedge}=-$ $23.04202+0.87771 \mathrm{X}_{1}$.

2. There is a positive and significant relationship between student discipline and mathematics learning outcomes of XI IPS class students in the even semester of SMA Negeri 1 Pleret 2015/2016 Academic Year. The simple correlation coefficient (r) between discipline and mathematics learning outcomes is 0.54328 . In addition, a simple regression equation for $\mathrm{Y}$ over $\mathrm{X}_{2}$ is also obtained. $\mathrm{Y}^{\wedge}=-41.84569+1.03263 \mathrm{X}_{2}$.

3. There is a positive and significant relationship between learning responsibilities with mathematics learning outcomes of students of class XI IPS even semester of SMA Negeri 1 Pleret Academic Year 2015/2016. Simple correlation coefficient (r) between learning responsibilities with 
mathematics learning outcomes of 0.44603. In addition, we also obtained a simple regression equation for $\mathrm{Y}$ over $\mathrm{X}_{3}$ is $\mathrm{Y}^{\wedge}=-38.45734+1.01563 \mathrm{X}_{3}$.

4. There is a positive and significant relationship between learning motivation and student discipline with the mathematics learning outcomes of class XI IPS students in the even semester of SMA Negeri 1 Pleret 2015/2016 Academic Year. The multiple correlation coefficient (R) between learning motivation and student discipline with mathematics learning outcomes is 0.62273 and the coefficient of determination $\left(R^{2}\right)$ is 0.38779 with a linear line equation $Y^{\wedge}=-58.80406+0.57974$ $\mathrm{X}_{1}+0.63987 \mathrm{X}_{2}$.

5. There is a positive and significant relationship between learning motivation and learning responsibility with mathematics learning outcomes of class XI IPS students in the even semester of SMA Negeri 1 Pleret 2015/2016 Academic Year. The correlation coefficient (R) between learning interest and learning environment with mathematics learning outcomes is 0.61373 and the coefficient of determination $\left(R^{2}\right)$ is 0.3767 with a linear line equation $Y^{\wedge}=-70.28272+0.7154 \mathrm{X}_{1}$ $+0.63211 \mathrm{X}_{3}$.

6. There is a positive and significant relationship between student discipline and learning responsibilities with mathematics learning outcomes of XI IPS class students in the even semester of SMA Negeri 1 Pleret 2015/2016 Academic Year. The correlation coefficient (R) between learning motivation and learning responsibility with mathematics learning outcomes is 0.5520 and the coefficient of determination $\left(R^{2}\right)$ is 0.3048 with a linear line equation $Y^{\wedge}=-54.6289+0.85467$ $\mathrm{X}_{2}+0,30882 \mathrm{X}_{3}$.

7. There is a positive and significant relationship between learning motivation, discipline and learning responsibility with mathematics learning outcomes of XI IPS class students in the even semester of SMA Negeri 1 Pleret Academic Year 2015/2016. The correlation coefficient (R) between learning motivation, discipline and learning responsibility with mathematics learning outcomes is 0.5998 and the coefficient of determination $\left(R^{2}\right)$ is 0.3598 with a linear line equation $\mathrm{Y}^{\wedge}=-73.3307+$ $0.3358 \mathrm{X}_{1}+0.4425 \mathrm{X}_{2}+0.5854 \mathrm{X}_{3}$.

\section{REFERENCES}

Amri,Sofan. 2013. Pengembangan \& Model pembelajaran dalam Kurikulum. Jakarta: Prestasi pustaka raya.

Diar Rudyanto.2010.Hubungan Antara Motivasi Berprestasi dan Disiplin Belajar dengan Prestasi Belajar Akuntansi Siswa Kelas X Program Keahlian Akuntansi SMK YPKK 1 Sleman Tahun Ajaran 2009/2010. Skripsi: UNY.

Sartono. 2014. Peningkatan Tanggung Jawab Belajar Melalui Layanan Penguasaan Konten Dengan Teknik Role Playing. Jurnal Pendidikan Matematika. vol 16.http://www.google.com/url?sa=t\&rct=j\&q=\&esrc=s\&source=web\&cd=1\&ved=0ahUKEwiP 18fZ0IPPAhVHgI8KHZeTCU8QFggfMAA\&url=http\%3A\%2F\%2Firpp.com\%2Findex.php\%2 Fdidaktikum\%2Farticle $\% 2$ Fdownload\%2F140\%2F138\&usg=AFQjCNHPCSqm5fwt9uIXpK_q ZpsSo7-Keg\&bvm=bv.132479545,d.c2I

Sardiman. 2012. Interaksi dan motivasi belajar mengajar. Jakarta: Rajawali Pers

Undang - UndangRepublik Indonesia No.20 Tahun 2003 Bab 1 Pasal 1 Sistem Pendidikan Nasional. 